\title{
Silesian Library in Katowice and Its Collection
}

\author{
Weronika Pawtowicz \\ Biblioteka Śląska, Katowice, Poland \\ werpaw5@gmail.com
}

\begin{abstract}
The Silesian Library in Katowice is a public library with a scientific profile which also performs the functions of a regional library. It was founded in 1922 as the Library of the Silesian Parliament and in 1936 became an independent institution named Józef Pitsudski Silesian Public Library. In 1952, the Library received the name Silesian Library and was proclaimed a scientific library. Today the collection of the Silesian Library counts more than 2.5 million items: books, periodicals, social life documents as well as special collections: manuscripts, old prints, cartographic materials, graphics, leaflets, music, records and films. Among them are many very valuable and a few unique ones, like Exercitia spiritualia by Saint Ignatius of Loyola (Amacusa 1596) and Jakob en zijn Heer by Diderot (Hague 1793). A lot of items from the collection of the Silesian Library can be seen in their digital version via the Silesian Digital Library.
\end{abstract}

Keywords: Silesian Library, Katowice, special collections, manuscripts, Library of the Lviv Theatre, old prints, graphics, cartographic materials, ephemera, Silesian Digital Library

The Silesian Library is a public library with a scientific profile. Since the year 2000, it also performs the functions of a regional library with the responsibility of supervising public communal libraries in the region.

The library was founded at the end of the year 1922 as the Library of the Silesian Parliament (Biblioteka Sejmu Śląskiego). Its collection - in the beginning mainly on law and social science - was growing rapidly not only by buying books and whole collections, but also by very valuable donations. Since 1934, it has been a regional library with the legal deposit for the prints from Silesia. In 1936, it became an independent institution named Józef Piłsudski Silesian Public Library (Śląska Biblioteka Publiczna im. Józefa Piłsudskiego). During the World War II, it was annexed to the Oberschlesische Landesbibliothek in Bytom - the scientific library formed in 1927, for the German part of Silesia. In January 1945, the library was taken over by the Polish authorities. In 1952 the Library received a new name, Silesian Library, and was proclaimed a scientific library. ${ }^{1}$

The Library's collection comprises documents belonging to all branches of knowledge, particularly on law, economy, social science, humanities, literature and popular editions. As a regional institution, it collects Silesiaca - all materials concerning Silesia, its history, geography, economy, culture. The Library edits the annual regional bibliography, catalogues of different groups of collections, scientific studies as well as magazines. Among the users of the library are researchers, teachers, students, pupils of various schools. The Library offers a wide range of information services, prepares exhibitions, concerts, lectures, cultural events for different groups of readers.

Today, after 95 years of its activity, the collection of the Silesian Library counts more than 2.5 million items - mainly books, periodicals, social life documents as well as special collections: manuscripts, old prints, cartographic materials, graphics, leaflets, music, records and films.

\footnotetext{
1 About the history of the Silesian Library see among others Jan Kantyka, ed., Biblioteka Śląska 1922-1972 (Katowice: Śląski Instytut Naukowy; Wydawnictwo "Śląsk", 1973); Barbara Maresz, Ze Lwowa do Katowic: przedwojenne ksiegozbiory lwowskie i kresowe w Bibliotece Śląskiej (Katowice: Biblioteka Śląska, 2002); Barbara Maresz, Źródła do dziejów Biblioteki Śląskiej w Archiwum Ossolineum (przechowywanym w Lwowskiej Naukowej Bibliotece im. W. Stefanyka) (Katowice: Biblioteka Śląska, 2008).
} 
The most valuable materials are kept in the Special Collections Department. The collection of manuscripts counts nearly 6.000 copies: documents, papers of families and individuals, materials of organizations and institutions, letters, memoirs, dissertations, biographies, sketches, notes, poems, movie scripts and others - written by hand, typescripts, computer prints. The most important are materials concerning Silesia, its history, geography, culture as well as people who lived and worked in that region.

The set of legal documents written on parchment cards by Italian notaries in the period from the $14^{\text {th }}$ to the $16^{\text {th }}$ century belongs to the oldest in the collections of the Silesian Library. The volume titled Miscellanea astrologica at alchymica, written in Latin in the $15^{\text {th }}$ century by a student of the Academy in Cracow (later Jagiellonian University), which contains the lectures on mathematic, astrology, astronomy and alchemy, is very interesting. On its cards, there is also a text of John of Głogów, Silesian scholar, astronomer, lecturer of the Academy.

The oldest manuscript in Polish is the compendium of law from the $16^{\text {th }}$ century: Ustawy Praua Polskiego dlya pamieczi krotko napisane (Acts of Polish Law Shortly for the Memory Written). The Library also holds a few documents of the kings of Poland - Władysław IV, Jan III Sobieski, Stanislaw August, and the emperor Francis II. The last one, the privilege for Süssmann Abraham Oppenheim, dated Wien, 1792, is written on parchment, bound in purple velvet and confirmed with the beautiful wax seal. There are also manuscripts of famous Polish and Silesian writers, among others Józef Ignacy Kraszewski, Henryk Sienkiewicz, Władysław Reymont, Gustaw Morcinek, Kazimierz Gołba. Worth mentioning are also three manuscripts written in Old Church Slavonic: Oktoich, ${ }^{2}$ Apostoł and Evangeliar.

The Library of the Lviv Theatre (Biblioteka Teatru Lwowskiego) forms a distinct group of manuscripts. ${ }^{3}$ It contains more than 5.000 manuscripts and prints of the plays performed in the Polish Theatre in Lviv for over 150 years - from the end of the $18^{\text {th }}$ century till 1945 . There are autographs of Polish original authors, like Michał Bałucki and translators of foreign works like Jan Kasprowicz and Lucjan Rydel. In this collection, there are many unpublished dramatic pieces. Very interesting for historians of theatre are copies with notes of directors, censors, prompters, actors and stage designers, which are also available in the collection.

The collection of historical prints in the Silesian Library counts more than 27.000, in which there are also 55 incunabula. The oldest one is Rainerius de Pisis's Pantheologia, printed in Nürnberg in 1474. Edited in 1475, Opus restitutionum by Franciscus de Platea is one of the very first prints which came out in Kraków by the travelling typographer Kasper Straube. This volume is the only libri catenatus in the Silesian Library. The copy of Hans Tucher's Reise in das gelobte Land (Augsburg 1486) is the only one in Poland. There are also some works of Polish and Silesian authors, like Laurentius Corvinus, John of Głogów, Nicolaus of Błonie, printed in the $15^{\text {th }}$ century.

The collection of $16^{\text {th }}, 17^{\text {th }}$ and $18^{\text {th }}$-century prints is very rich and interesting. It contains works on the wide range of themes (for instance religion, law, medicine, mathematics, physics, astronomy, architecture, biology, history, art, archeology, geography, technique, military, literature), written by authors from different countries, edited by the best printers in Europe, for instance by Aldus Manutius, Christophe Plantin, Johannes Froben, Johannes Oporinus, Elzeviers, Estiennes.

Among the numerous old prints of the $16^{\text {th }}$ century are 645 works (in 719 copies) qualified as Polonica and Silesiaca - works connected to Poland and Silesia by their authors, language, place

\footnotetext{
2 This manuscript is described in the article by Olimpia Mitric, "Rękopis z okresu panowania Eliasza II z Biblioteki Śląskiej w Katowicach”, Książnica Śląska t. 29 (2016): 85-95.

${ }^{3}$ There are two parts of the inventory of that collection by now: Barbara Maresz, Biblioteka Teatru Lwowskiego. Inwentarz kolekcji egzemplarzy teatralnych (rẹkopisów, maszynopisów i druków) ze zbiorów Biblioteki Ślaskiej w Katowicach, Cz. 1, sygnatury BTLw 1 BTLw 1500, vol. 1-2 (Katowice: Biblioteka Śląska, 2004); Barbara Maresz, Biblioteka Teatru Lwowskiego. Inwentarz kolekcji egzemplarzy teatralnych (rękopisów, maszynopisów i druków) ze zbiorów Biblioteki Śląskiej w Katowicach. Cz. 2, Sygnatury BTLw 1501-BTLw 3200, vol. 1-2 (Katowice: Biblioteka Śląska, 2011).
} 
of edition or theme. ${ }^{4}$ There are a few editions of Bible translated into Polish, printed in Kraków and Brześć, both for catholic and reformed Church. There are also editions of the Holy Bible for the Orthodox Church printed by Ivan Fedorov in Old Church Slavonic. In 1573-1574, in Lwów, he printed the New Testament (Apostoł. Dejanija apostolskaja i poslanija sobornaja i poslanija svjatogo apostola Pavla), and in 1581, in Ostróg, the first complete printed edition of the Bible, called the Ostroh Bible. Besides, there are works on religion, law, politics, medicine, history, geography, astronomy, biography, poetry. They were printed in Kraków, Poznań, Gdańsk, Zamość, in Polish in that century Lwów, Wilno, Królewiec, Brześć Litewski and in Silesia in Wrocław, Nysa, Legnica, and also in Germany, Italy, Czech, Belgium and Netherland, France, Switzerland.

In the whole collection of old prints, it is worth to mention the eight-volume Bible edited by Christophe Plantin, in five languages, with rich commentaries (Antwerpen 1569-1573). There are, illustrated with beautiful copperplates, works by Johannes Hevelius, famous astronomer from Gdańsk: Machina Coelestis (Gdańsk 1673-1679) and Prodromus astronomiae (Gdańsk 16871690), in which was also his Firmamentum Sobiescianum. Another astronomer who lived in SilesiaMaria Cunitia (Cunitz) called "Silesian Pallas", was a very well-educated woman who spoke seven languages. Her work Urania propitia sive Tabulae astronomicae mire faciles (Oleśnica 1650), edited in Latin and German, contains the improved version of the Johann Kepler's Rudolphine Tables. On the cards of the copy kept in the Silesian Library, we can find a lot of manuscript notes made by a former reader.

There is a very interesting, small book, bound in wooden slats and covered with red velvet. It is a very popular work by Saint Ignatius of Loyola, Exercitia spiritualia, which is considered unusual thanks to the place and date of its printing - the Jesuit college in Amacusa, Japan, 1596. ${ }^{5}$ It is most likely the only copy existing in the world.

The book entitled Jakob en zijn Heer. Uit de nagelaten ongedrukte schriften van Diderot, printed in the Hague in 1793, is definitely unique ${ }^{6}$. It is the Dutch translation of Diderot's novel Jacque the Fatalist and His Master based on the German version of that novel. Jakob und sein Herr. Aus Diderots ungedrucktem Nachlasse was printed in Berlin in 1792. That book was illustrated with two copperplates by Daniel Chodowiecki, which was redone for the Hague edition by Theodorus de Roode. Both the German and Dutch translations of the Diderot's novel were printed earlier than the first French edition, which is dated 1796.

The collection of more than 21.000 units of cartographic materials is also wide and interesting. It contains different types of atlases, maps and plans, ancient and contemporary. Many of them are engraved in copperplates and then colored by hand. Theatrum Orbis Terrarum by Abraham Ortelius (Antwerpen 1574), the great atlas which includes a map of Silesia by Martin Helwig and a map of Poland by Wacław Grodecki, belongs to the most valuable ones. Edited in Amsterdam in 1630, Atlas sive Cosmographicae meditationes de fabrica mundi by Gerard Mercator has admirable etched and colored title page. The first atlas of Silesia, prepared by Johann Wolfgang Wieland and Matthäus Schubart, was edited in Nürnberg in 1752. It contains four general maps of Silesia and sixteen maps of Silesian duchies, each with beautiful cartouche. Also, in the middle of the $18^{\text {th }}$ century, Friedrich Bernhard Werner edited eleven series of the views of the Silesian towns, castles and monasteries under the common title Scenographia Urbium Silesiae (Nürnberg 1737-1752).

Graphics form the separate category in special collections. There are drawings, woodcuts, copperplates, lithographs made by many artists, such as Napoleon Orda, Alexander Duncker, Friedrich August Tittel, Carl Mattis, Friedrich Koska, Paweł Steller. The graphics show the

\footnotetext{
${ }^{4}$ These works are included in the catalogue by Weronika Pawłowicz and Teresa Roszkowska, eds., Polonica i silesiaca XVI wieku w zbiorach Biblioteki Śląskiej (Katowice: Biblioteka Śląska, 2013).

${ }^{5}$ Descripted in the article: Weronika Pawłowicz, „Biały kruk w zbiorach Biblioteki Śląskiej. Exercitia spiritualia Ignacego Loyoli (Amacusa 1596)", Książnica Śląska t. 29 (2016): 11-29.

${ }^{6}$ David Adams, Bibliographie des auvres de Denis Diderot, 1739-1900, t. 2 (Paris: Centre international d'étude du XVIII siècle, 2000 ), 202.
} 
beautiful landscapes of Poland and Silesia. The scenes of the $19^{\text {th }}$-century industrial towns of Upper Silesia are particularly interesting for contemporary readers. These we can admire on lithographs made by Ernst Wilhelm Knippel, in the photos by L. A. Lamche and Max Steckel and also on the old postcards. ${ }^{7}$

Among graphics is also a numerous collection of book plates of individual possessors and institutions. Every two years, the Silesian Library organizes the International Review of Woodcutter's and Linoleum Ex-Libris Print. ${ }^{8}$

Ephemera, containing more than 7.000 items, form another big group. Among them very important are those printed during the World War I and in time of Upper Silesia Plebiscite and Silesian uprisings (1919-1921). ${ }^{9}$

The most valuable items of the special collections can be seen in their digital version via the Silesian Digital Library. It was established in 2006, by the Silesian Library together with the Library of the University of Silesia. ${ }^{10}$ At present, it unites over 50 institutions working in the region - libraries, archives, museums, associations. The library opens access to digital copies of the important and valuable materials creating the cultural heritage of Silesia.

\section{Literature:}

1. Adams, David. Bibliographie des auvres de Denis Diderot,1739-1900, t. 2. Paris: Centre international d'étude du XVIII siècle, 2000.

2. Bratkowski, Przemysław, Lis Remigiusz and Marek Szulc, eds. Cyfrowa pamięć regionu. 10 lat Ślaskiej Biblioteki Cyfrowej. Katowice: Biblioteka Śląska, 2017.

3. Duda-Koza, Agata and Weronika Pawłowicz. Tylko z Polską... Druki ulotne z okresu powstań ślaskich i plebiscytu w zbiorach Biblioteki Ślaskiej. Katowice: Biblioteka Śląska, 2008.

4. Duda-Koza, Agata et al., eds. Daniel Mikołaj Chodowiecki (1726-1801). Ryciny ze zbiorów graficznych Biblioteki Śląskiej. Katowice: Biblioteka Śląska, 2012.

5. Dyzia, Ilona and Agnieszka Jachymczyk. Miasto zachwycajacego szczegółu: Katowice na dawnej pocztówce: z kolekcji Biblioteki Śląskiej. Katowice: Biblioteka Śląska, 2007.

6. Jabłko Lucyna, Jolanta Kowalczyk and Elżbieta Tyrna-Danielczyk. Międzynarodowe Przeglądy Ekslibrisu Drzeworytniczego i Linorytniczego im. Pawła Stellera, Katowice 2006-2012 = International Reviews of Woodcutter's and Linoleum Ex-libris Print named after Paweł Steller, Katowice 2006-2012. Katowice: Biblioteka Śląska, 2016.

7. Kantyka, Jan, ed. Biblioteka Śląska 1922-1972. Katowice: Śląski Instytut Naukowy; Wydawnictwo "Śląsk", 1973.

8. Kowalczyk, Jolanta and Lucyna Solarz. „Zielony Śląsk” na dawnej pocztówce: powiat bielski, cieszyński i żywiecki: ze zbiorów Biblioteki Śląskiej. Katowice: Biblioteka Śląska, 2016.

9. Maresz, Barbara. Biblioteka Teatru Lwowskiego: inwentarz kolekcji egzemplarzy teatralnych (rękopisów, maszynopisów i druków) ze zbiorów Biblioteki Śląskiej w Katowicach. Cz. 1. Sygnatury BTLw 1 - BTLw 1500 T. 1-2. Katowice: Biblioteka Śląska, 2004.

\footnotetext{
${ }^{7}$ Exemplary catalogues: Agata Duda-Koza et al., eds. Daniel Mikołaj Chodowiecki (1726-1801). Ryciny ze zbiorów graficznych Biblioteki Śląskiej (Katowice: Biblioteka Śląska, 2012); Ilona Dyzia and Agnieszka Jachymczyk, Miasto zachwycającego szczegółu: Katowice na dawnej pocztówce: z kolekcji Biblioteki Śląskiej (Katowice: Biblioteka Śląska, 2007); Jolanta Kowalczyk and Lucyna Solarz, "Zielony Śląsk" na dawnej pocztówce: powiat bielski, cieszyński i żywiecki: ze zbiorów Biblioteki Śląskiej (Katowice: Biblioteka Śląska, 2016).

${ }^{8}$ Catalogue: Lucyna Jabłko et al., Międzynarodowe Przeglady Ekslibrisu Drzeworytniczego i Linorytniczego im. Pawła Stellera, Katowice 2006-2012 = International Reviews of Woodcutter's and Linoleum Ex-libris Print named after Pawet Steller, Katowice 2006 -2012 (Katowice: Biblioteka Śląska, 2016).

${ }^{9}$ These ephemera are included in the printed catalogues by Barbara Maresz and Mateusz Ściążko, Wielka Wojna na słowa. Druki ulotne z lat 1914-1918 w zbiorach Biblioteki Śląskiej (Katowice: Biblioteka Śląska, 2014); Agata Duda-Koza and Weronika Pawłowicz, Tylko z Polską... Druki ulotne z okresu powstań Śląskich i plebiscytu w zbiorach Biblioteki Śląskiej (Katowice: Biblioteka Śląska, 2008).

${ }^{10}$ See: Przemysław Bratkowski, Remigiusz Lis and Marek Szulc, eds. Cyfrowa pamięć regionu. 10 lat Śląskiej Biblioteki Cyfrowej (Katowice: Biblioteka Śląska, 2017).
} 
Pawłowicz W. "Silesian Library in Katowice and Its Collection", 33-37

10. Maresz, Barbara. Biblioteka Teatru Lwowskiego: inwentarz kolekcji egzemplarzy teatralnych (rękopisów, maszynopisów i druków) ze zbiorów Biblioteki Śląskiej w Katowicach. Cz. 2. Sygnatury BTLw 1501 - BTLw 3200. Katowice: Biblioteka Śląska, 2011.

11. Maresz, Barbara. Ze Lwowa do Katowic: przedwojenne księgozbiory lwowskie i kresowe w Bibliotece Śląskiej. Katowice: Biblioteka Śląska, 2002.

12. Maresz, Barbara. Źródła do dziejów Biblioteki Śląskiej w Archiwum Ossolineum (przechowywanym w Lwowskiej Naukowej Bibliotece im. W. Stefanyka). Katowice: Biblioteka Śląska, 2008.

13. Maresz, Barbara and Mateusz Ściążko. Wielka Wojna na słowa : druki ulotne z lat 1914-1918 w zbiorach Biblioteki Śląskiej. Katowice: Biblioteka Śląska, 2014.

14. Mitric, Olimpia. „Rękopis z okresu panowania Eliasza II z Biblioteki Śląskiej w Katowicach”. Książnica Śląska t. 29 (2016): 85-95.

15. Pawłowicz, Weronika. „Biały kruk w zbiorach Biblioteki Śląskiej. Exercitia spiritualia Ignacego Loyoli (Amacusa 1596)". Książnica Śląska t. 29 (2016): 11-29.

16. Pawłowicz, Weronika and Teresa Roszkowska, eds. Polonica i silesiaca XVI wieku w zbiorach Biblioteki Śląskiej. T. 1-2. Katowice: Biblioteka Śląska, 2013.

\title{
Biblioteka Śląska w Katowicach i jej zbiory
}

\begin{abstract}
Abstrakt
Biblioteka Śląska w Katowicach jest biblioteką publiczną o profilu naukowym, pełniącą również funkcję biblioteki wojewódzkiej. Powstała w 1922 r. jako Biblioteka Sejmu Ślą̧siego, a w 1936 r. stała się instytucją samodzielną pod nazwą Śląska Biblioteka Publiczna im. Józefa Piłsudskiego. W 1952 r. otrzymata miano Biblioteka Śląska i zyskała status biblioteki naukowej. Dzisiaj zbiory Biblioteki Śląskiej liczą ponad 2,5 miliona egzemplarzy. Są to książki, czasopisma, dokumenty życia społecznego, a także zbiory specjalne: rękopisy, stare druki, kartografia, grafika, ulotki, nuty, dokumenty dźwiękowe i filmy. Wśród nich jest wiele cennych i kilka unikatowych, takich jak Exercitia Spritualia św. Ignacego Loyoli (Amacusa 1596) czy Jakob en zijn Heer Diderota (Haga 1793). Wiele egzemplarzy ze zbiorów Biblioteki Śląskiej jest udostępnionych w wersji cyfrowej w Śląskiej Bibliotece Cyfrowej.
\end{abstract}

Słowa kluczowe: Biblioteka Śląska, Katowice, zbiory specjalne, rękopisy, Biblioteka Teatru Lwowskiego, stare druki, grafika, kartografia, ulotki, Śląska Biblioteka Cyfrowa

\section{Шлеска библиотека у Катовицама и њен фонд}

\section{Резиме}

Шлеска библиотека у Катовицама је јавна библиотека научног профила, која врши и функцију матичне библиотеке. Основана је 1922. године као Библиотека Шлеског парламента, а 1936. постала је независна институција под називом Шлеска јавна библиотека „Јозеф Пилсудски”. Године 1952. добија назив Шлеска библиотека и бива проглашена научном библиотеком. Данас фонд Шлеске библиотеке броји више од 2,5 милиона предмета: књиге, часописе, документарну грађу о друштвеном животу, као и специјалне колекције: рукописе, старе отиске, картографски материјал, графике, летке, музику, плоче и филмове. Међу њима су многи врло вредни и неколико јединствених, као што су Exercitia spiritualia од Светог Игнација Лојолског (Амакуса, 1596) и Jakob en zijn Heer од Дидроа (Хаг, 1793). Велики број јединица које припадају фонду Шлеске библиотеке доступан је и у дигиталној верзији, посредством Шлеске дигиталне библиотеке.

Кључне речи: Шлеска библиотека, Катовице, посебни фондови, рукописи, Библиотека Позоришта у Лавову, стари отисци, графике, картографска грађа, ефемерна грађа, Шлеска дигитална библиотека 